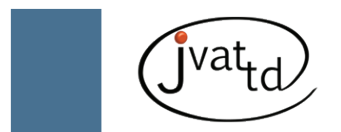

\title{
Maintaining rear-fanged snakes for venom production: an evaluation of mortality and survival rates for Philodryas olfersii and P. patagoniensis in captivity
}

Braz HB (1, 2), Rocha MMT (1), Furtado MFD (1)

(1) Laboratory of Herpetology, Butantan Institute, São Paulo, São Paulo State, Brazil; (2) Laboratory of Ecology and Evolution, Butantan Institute, São Paulo, São Paulo State, Brazil.

\begin{abstract}
This study evaluates the mortality and average survival rates of captive female Philodryas olfersii and Philodryas patagoniensis snakes maintained for venom production. Also, two factors likely to reduce captive survival were studied - body condition at admission and seasonality. Mortality peaks occurred during the second month in captivity. More than half the individuals were dead at the end of the third month. This suggests that the first three months in captivity are the most critical in terms of survival and adaptation. Females collected and admitted during spring and summer lived less time than those collected in autumn and winter. As gravidity and egg-laying occur during spring and summer, we suggest that the lower survival rates in these seasons may be due to high costs and stress involved in these reproductive events. Unexpectedly, body mass and body condition were poor predictors of survival in captivity. Our results have important implications in maintaining snakes for venom production. We propose some prophylactic measures to minimize the deleterious impacts of captivity during the adaptation period.
\end{abstract}

Key words: animal husbandry, snake venom, seasonal variation, body mass index.

\section{INTRODUCTION}

Rear-fanged snakes are responsible for a significant number of snakebites in Brazil and are therefore considered a public health problem (1). Although considered nonvenomous, there are several important clinical manifestations such as abrasions, pain, local hemorrhage, swelling and erythema $(1,2)$. Furthermore, there is at least one report of death caused by a rear-fanged snake, Philodryas olfersii in southern Brazil (3). As a result, the biological activity and biochemical characterization of venom from these animals has received more attention in this decade (47). However, unlike venomous snakes, secretion from the venom gland of rear-fanged snakes is difficult to obtain in suitable quantities, so some species have started being kept in captivity at Butantan Institute Herpetology Laboratory
(LHIB) with the aim of producing venom from periodical extractions.

Establishing a large scale snake breeding program for venom production substantially differs from one destined for exhibition or biological study. This is because the captive environment for such a purpose must combine the practicability in maintaining a large number of individuals with their needs and welfare. Leloup (8) suggests three systems for maintaining snakes on a large scale for venom production: intensive, semi-extensive, and extensive captivity. Although all have advantages and disadvantages, intensive captivity is widely adopted in breeding snakes for venom production (8-11). This system simplifies maintenance by allowing constant easy inspections, individual control of feeding and health, temperature control according to specific requirements, and smaller installations (8). 
A number of reviews on snake maintenance in captivity suggest that the combination of variables such as temperature, humidity, light, feeding, physical space, and sanitation is required for suitable husbandry (12-14). However, even with all this care, adaptation to captivity is not assured and many individuals die within two years of acquisition (15). Thus, any attempt to understand factors that may affect captive survival is central to the successful implementation of a snake colony for venom production.

The major cause of death in captive reptiles is judged to be their inability to adapt to the captive environment; this is called maladaptation syndrome $(15,16)$. This syndrome accounted for about $80 \%$ of captive snake deaths at Philadelphia Zoological Garden and can be defined as the pathological effects of stress on an animal associated with a captive environment (15). Maladaptation syndrome may cause anorexia, emaciation (even though animals may be feeding), tissue fragility, increased susceptibility to infection (even with normally innocuous organisms), parasite overgrowth, gut ulceration, reduced growth, and reproductive failure (15, 16). The end result is that animals are wasted and all fat reserves are depleted.

However, a number of other factors are likely to affect captive survival (e.g. seasonality and age). Herpetological literature on snake husbandry mostly deals with the general aspects of maintenance or with the deleterious effects of diseases and parasites $(8,10,14,15,17-19)$. In this paper we examine the mortality rates and average survival in captive females of rear-fanged $P$. olfersii and $P$. patagoniensis snakes maintained under an intensive captivity system for venom production at LHIB. In addition, we explore factors other than disease which are likely to reduce survival in captivity. Specifically, we attempt to answer two questions:

- Does average survival in captivity differ depending on the season in which snakes were collected? Seasonality affects several biological processes in snakes (e.g. activity patterns and reproduction). Thus, the effects of maladaptation to captivity are also likely to vary between seasons. Indeed, differential survival between seasons has previously been observed in at least one snake species maintained in captivity for venom production. Bothrops jararacussu snakes captured during spring and summer (wet season) showed higher survival than those captured in autumn and winter (dry season) (9).

- Are survival rates in captivity dependent on snake fat reserves at admission? Because the most noticeable result of maladaptation syndrome is the depletion of all fat reserves in an individual, we hypothesized that animals weighing more in relation to their body size (and presumably with larger fat reserves) might survive longer in captivity (15).

We therefore investigated the periods of higher susceptibility to the captive environment with the aim of increasing knowledge on factors that may impact survival. Consequently, we expected to gather information to help develop effective husbandry practices which assure animal welfare.

\section{MATERIALS AND METHODS}

\section{Study Species}

P. olfersii and P. patagoniensis (Figure 1) are medium-sized (up to $1.2 \mathrm{~m}$ snout-vent length, $280 \mathrm{~g}$ ) diurnal snakes widely distributed in South America and are largely sympatric (20-23). P. olfersii is mainly found in forested areas and forest edges and displays semi-arboreal habits, whereas $P$. patagoniensis is mostly found in open habitats and is predominantly terrestrial $(21,22)$. Both species are diet generalists feeding on frogs, lizards, birds, and mammals $(21,22)$. Female reproduction is seasonal in both species with vitellogenesis occurring from May to January for P. olfersii and from August to December for P. patagoniensis and gravid females are found from September (late winter) to January (early summer) (24). These species are responsible for a significant number of snakebites in Brazil (1, $25,26)$. The mortality rates and average survival times of 36 adult female $P$. olfersii and 56 adult female $P$. patagoniensis maintained in captivity for venom harvest were analyzed. Most females were found in São Paulo state, Brazil, between May 2003 and July 2008.

\section{Maintenance Protocol}

Newly-arrived snakes in the laboratory were submitted to visual surveys. Only active adult individuals of healthy appearance were selected. All individuals were washed with $0.2 \%$ trichlorfon solution (Neguvon ${ }^{\oplus}$, Bayer, Brazil) at admission 

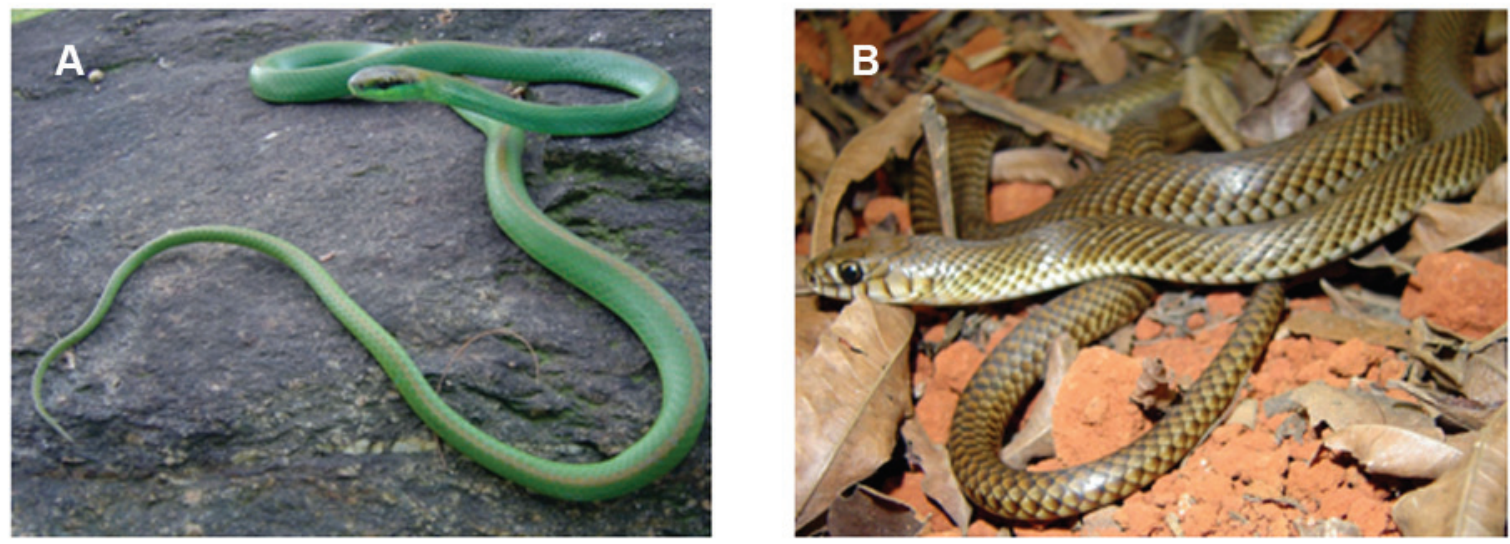

Figure 1. Adult individuals of (A) Philodryas olfersii and (B) Philodryas patagoniensis. Photos by Silvia R. Travaglia-Cardoso.

and seven days later to eliminate ectoparasites (27). Snakes were sexed (by hemipenis eversion), measured (to nearest millimeter), and weighed (to nearest $0.1 \mathrm{~g}$ ). The snakes were maintained under an intensive captivity system (8).

Specimens were kept individually in plastic cages (SanRemo, Brazil, 975; $564 \times 385 \times 371$ $\mathrm{mm}$ for larger individuals and SanRemo, Brazil, $965 ; 400 \times 270 \times 362 \mathrm{~mm}$ for smaller ones), with corrugated cardboard as substrate, a water bowl (replaced every other day), and previously disinfected furniture including stones, plastic tubes (for shelter), and tree branches. Cages, bowls, and furniture were changed weekly and disinfected with $4 \%$ sodium hypochlorite solution. Room temperature averaged $25^{\circ} \mathrm{C}$ (range $20-30^{\circ} \mathrm{C}$ ). Photoperiod corresponded to natural light entering room windows.

Snakes were fed monthly with mice (Mus musculus) in quantities corresponding to approximately $10 \%$ the snake weight. If snakes refused to feed for two consecutive months they were force-fed with freshly killed mice. Venom was also extracted monthly, but three weeks after feeding. Snakes were intraperitoneally (IP) inoculated with $10 \mathrm{mg} / \mathrm{kg}$ pilocarpine solution diluted in $0.85 \%$ saline solution to induce venom secretion from Duvernoy glands (28). The venom was collected by placing a $100-\mu \mathrm{L}$ capillary tube over each fang (29). During venom extraction, snakes were manipulated for 5 to 10 minutes. Capillary tubes were changed after each venom extraction and fangs disinfected with $0.2 \%$ alcoholic iodine solution to prevent bacterial infection. Necropsy or histopathological exams were not performed to determine causes of death in studied snakes.

\section{Data Analysis}

All data were tested for normality using the Kolmogorov-Smirnov test and for homogeneity of variances using the Bartlett's test. Data were log-transformed when necessary to satisfy the assumptions for parametric tests. Values are presented throughout as mean \pm 1 standard error and the significance level of all tests was $\alpha=0.05$.

Survival in captivity was defined as the number of days between the date admitted to captivity and the date of death. Differences in average survival between species were examined with the $t$-test. For analysis of mortality rates during the captivity period we considered a class interval of 30 days because that was also the period between feeding sessions and venom extractions. Differences in distribution of deaths across class intervals were examined with chi-square analysis. Mortality rates were defined as the ratio of number of deaths over total number of individuals analyzed.

In an attempt to estimate female fat reserves we calculated their body condition, which indicates whether individuals are relatively light or heavy for their body size. Body condition was defined as the residuals from the linear regression of logtransformed body mass on log-transformed body length (both at admission) (30). Thus, high body condition values indicate relatively large mass per unit of body length and presumably larger stored energy. 
Linear regression analyses were performed to test for the influence of morphological traits at admission (body condition, body mass, and body size) on survival. Seasons were assigned as summer (January to March), autumn (April to June), winter (July to September) and spring (October to December) and female reproductive status (gravid or non-gravid) was determined by palpation or the occurrence of egg-laying in captivity. Seasonal differences in survival rates were compared by one-way ANOVA followed by Tukey's post hoc multiple comparisons test to determine how survival differed each season.

\section{RESULTS}

\section{Mortality Rates}

The proportion of deaths for both species was not equally distributed over the months (Figure 2 ). The highest mortality level was observed during the second month in captivity when $33.3 \%$ of female $P$. olfersii $\left(\chi^{2}=84.34, \mathrm{df}=18, p=\right.$ 0.0000 ; Figure 2$)$ and $28.8 \%$ of $P$. patagoniensis $\left(\chi^{2}\right.$ $=217.52, \mathrm{df}=30, p=0.0000$; Figure 2) died.

Mortality curves were also similar for both species (Figure 2). At the end of the second month in captivity the number of accumulated deaths was about $40 \%$ of the total and at the end of the third month more than half (about 61\%) the individuals had died (Figure 3). Mortality curves continued to increase similarly in both species up to of the end the fourth month, when the death rate for $P$. olfersii slightly slowed against P. patagoniensis (Figure 3). At the end of the tenth month about $94 \%$ of females from both species had died. The longest surviving captive $P$. olfersii individual lived 544 days and $P$. patagoniensis lived 902 days after entering the laboratory.

Does average survival in captivity differ depending on the season in which snakes were collected?

General survival in captivity averaged $120.8 \pm$ 19.9 days (range $=14-544 ; \mathrm{n}=36$ ) for $P$. olfersii and $108.2 \pm 19.2$ days (range $=20-902 ; \mathrm{n}=52$ ) for $P$. patagoniensis, but did not differ between species $(t=0.71, \mathrm{df}=86, p=0.48)$. Survival rates varied significantly depending on the seasons in which snakes were captured both for $P$. olfersii (one-way ANOVA: $F_{3.32}=8.73 ; p=0.0002$ ) and P. patagoniensis (one-way ANOVA: $F_{3.48}=4.40 ; p$ $=0.008)$. The lowest survival rates for $P$. olfersii

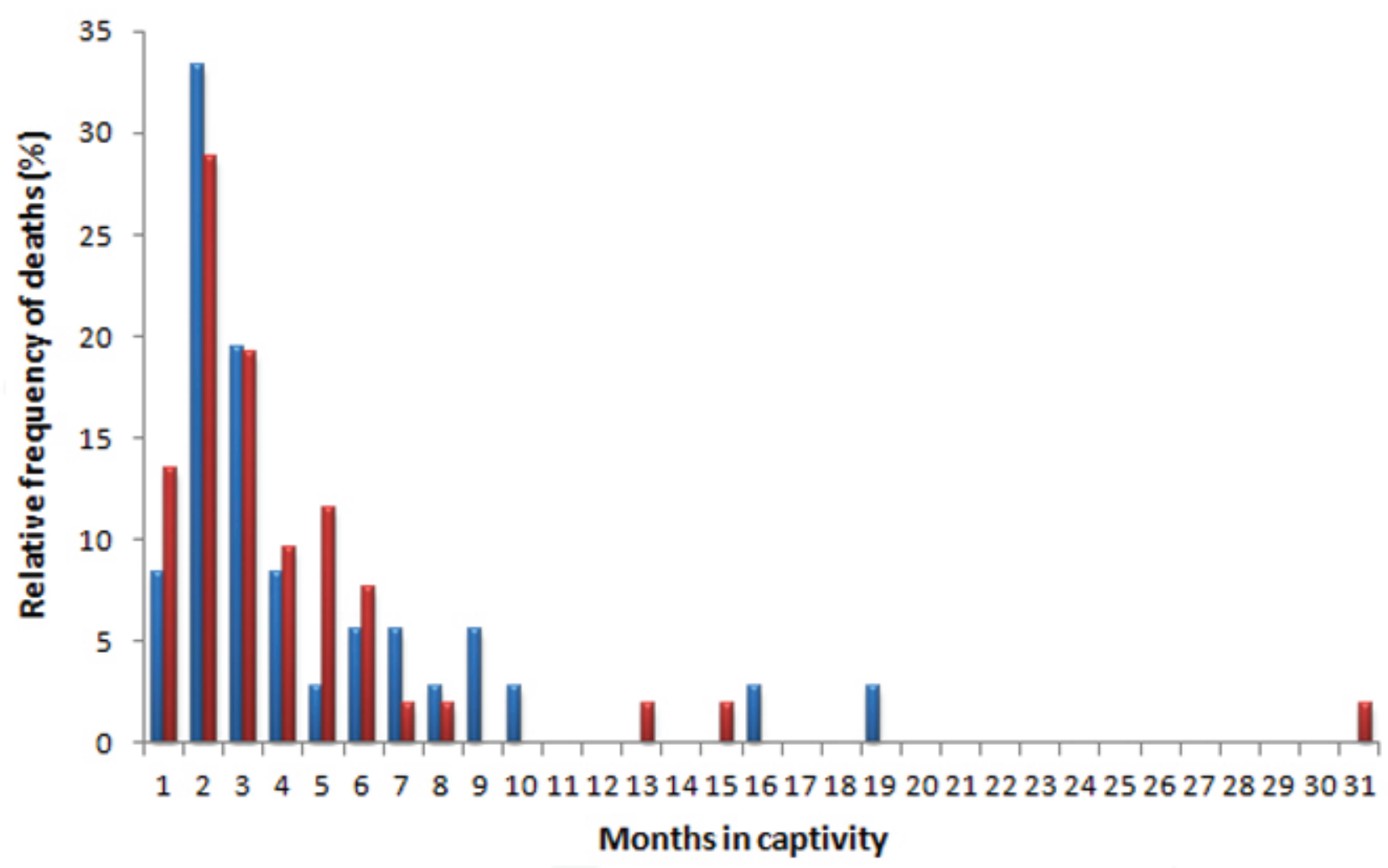

Figure 2. Relative monthly mortality frequencies for Philodryas olfersii (blue bars) and Philodryas patagoniensis (red bars) held in captivity for venom extraction. 


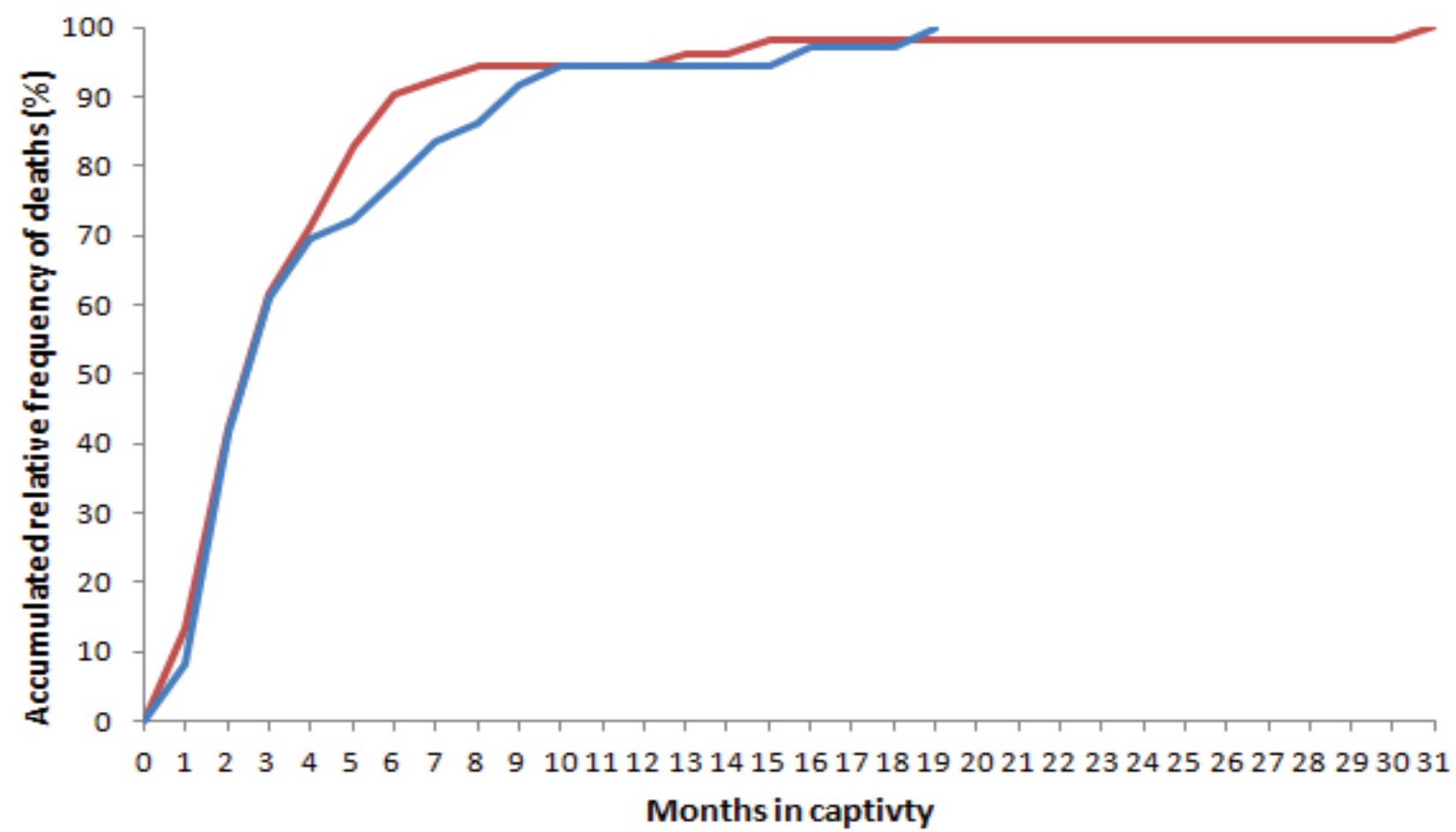

Figure 3. Mortality curves for captive Philodryas olfersii (blue line) and Philodryas patagoniensis (red line) after admission in laboratory.
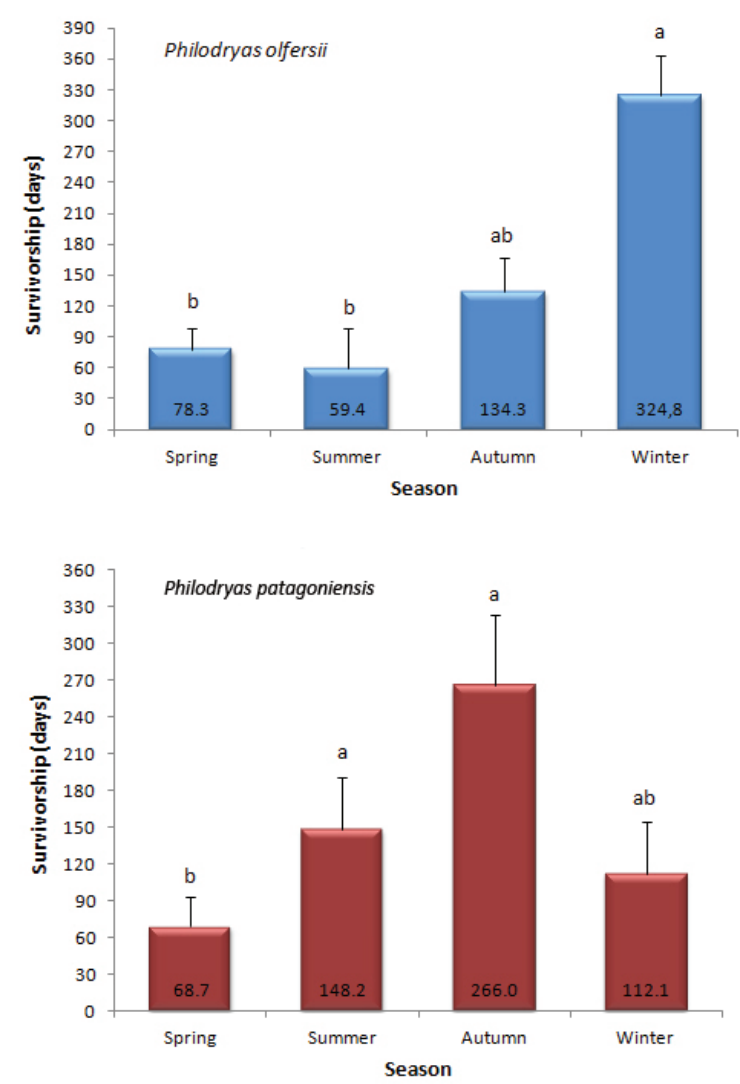

Figure 4. Mean survival against capture season for female Philodryas olfersii and Philodryas patagoniensis maintained in captivity for venom extraction. Seasons with the same letter are not significantly different (Tukey's post-hoc test, $a=$ $0.05, a>b$ ). Error bars represent standard error. were observed in females captured during spring and summer (i.e. the whole wet season) and for $P$. patagoniensis captured in spring (first half of wet season; Figure 4). However, the highest survival rates for $P$. olfersii were observed in females captured during winter and for $P$. patagoniensis captured in summer and autumn (Figure 4).

Are survival rates in captivity dependent on snake fat reserves (body condition) at admission?

At admission, female $P$. olfersii $(\mathrm{n}=36)$ had an average snout-vent length (SVL) of $883.1 \pm$ $24.5 \mathrm{~mm}$ (range: $510-1080 \mathrm{~mm}$ ), body mass 161.5 $\pm 13.3 \mathrm{~g}$ (range: $22-320 \mathrm{~g}$ ), and body condition indexes ranging from -0.275 to 0.253 . For $P$. patagoniensis females $(\mathrm{n}=52)$, SVL averaged $902.9 \pm 28.2 \mathrm{~mm}$ (range: $455-1550 \mathrm{~mm}$ ), body mass $220.4 \pm 17.0 \mathrm{~g}$ (range: $30-668 \mathrm{~g}$ ), and body condition indexes ranged from -0.278 to 0.824 .

For both species, linear regression analysis showed that longevity in captivity was not related to any of these morphological traits at admission. Snakes did not live longer or less because of their initial body size ( $P$. olfersii: $r^{2}=0.004 ; \mathrm{n}=36 ; p=$ 0.71 and $P$. patagoniensis: $r^{2}=0.019 ; \mathrm{n}=52 ; p=$ 0.33 ), body mass ( $P$. olfersii: $r^{2}=0.025 ; \mathrm{n}=36 ; p$ $=0.35$ and $P$. patagoniensis: $r^{2}=0.055 ; \mathrm{n}=52 ; p=$ 0.09 ), or body condition (P. olfersii: $r^{2}=0.091 ; \mathrm{n}$ 
$=36 ; p=0.07$ and $P$. patagoniensis: $r^{2}=0.049 ; \mathrm{n}=$ $52 ; p=0.11)$ at admission.

Because gravidity usually affects body mass measurements and may cause bias we reran analysis using only nongravid snakes. This also showed that longevity in captivity is not related to body size ( $P$. olfersii: $r=0.002 ; \mathrm{n}=22 ; p=0.83$ and $P$. patagoniensis: $\left.r^{2}=0.006 ; \mathrm{n}=38 ; p=0.64\right)$, body mass ( $P$. olfersii: $r^{2}=0.021 ; \mathrm{n}=22 ; p=0.52$ and $P$. patagoniensis: $\left.r^{2}=0.006 ; \mathrm{n}=38 ; p=0.64\right)$, or body condition ( $P$. olfersii: $r^{2}=0.127 ; \mathrm{n}=22 ; p=0.10$ and $P$. patagoniensis: $r^{2}=0.0003 ; \mathrm{n}=38 ; p=0.92$ ).

Body measurements at admission were compared between long-lived (survival over three months) and short-lived (under three months) individuals. Long-lived and short-lived P. olfersii individuals showed similar body size, body mass, and body condition (Table 1). The same was observed in $P$. patagoniensis only for body size (Table 1), as short-lived individuals were heavier (relative to body size) at admission than their long-lived counterparts (Table 1).

\section{DISCUSSION}

From our data we were able to identify periods with higher mortality rates of Philodryas olfersii and $P$. patagoniensis kept in captivity for venom extraction. The data also supported the idea of differential survival across the seasons, but did not support the hypothesis that heavier animals (presumably with larger fat reserves) might survive longer in captivity.
The literature does have information dealing with the maintenance of captive snakes for venom production $(8-11,17,27)$. However, data on mortality and survival rates are only available for a few species, such as the venomous snakes Bothrops jararacussu and Micrurus corallinus $(9,11)$. Both mortality and average survival rates differ between such species. General mean survival in these species was slightly higher $(\sim 6$ months) than for P. olfersii ( 4.0 months) and P. patagoniensis ( $\sim 3.6$ months). Also, mortality peaks seem to occur later for M. corallinus and B. jararacussu than for Philodryas. For instance, about $60 \%$ of deaths in captivity were after three months for Philodryas but were after six months for B. jararacussu. It could be argued that this was an artifact of admitting unhealthy individuals.

In this study, newly acquired individuals were not dewormed or put quarantine before admission to captivity $(12,14)$. The only prophylactic measures performed were visual surveys and preventive treatment against ectoparasites. Injured or apathetic individuals were not admitted to the animal house.

We judged that other factors may have been more important in reducing Philodryas mean survival time in captivity. Firstly, venom extraction from viperids and elapids at our laboratory is accomplished with animals almost unconscious after submission to anoxia by $\mathrm{CO}_{2}(31,32)$. However, venom extraction from rear-fanged snakes is performed with the animals completely conscious. This is because of

Table 1. Mean body measurements at admission for long-lived (over three months) and short-lived individuals (under three months). Values in bold indicate significant differences between long and shortlived individual

\begin{tabular}{|c|c|c|c|c|c|}
\hline \multirow{2}{*}{ Species/variable } & \multicolumn{2}{|r|}{ Short-lived } & \multicolumn{2}{|r|}{ Long-lived } & \multirow{2}{*}{ Statistical test } \\
\hline & $\mathrm{n}$ & Mean \pm SD & $\mathrm{n}$ & Mean \pm SD & \\
\hline \multicolumn{6}{|l|}{ P. olfersii } \\
\hline Body size (mm) & 22 & $896.9 \pm 150.4$ & 14 & $861.4 \pm 143.7$ & $t=0.70 ; \mathrm{df}=34 ; p=0.49$ \\
\hline Body mass (g) & 22 & $164.8 \pm 80.4$ & 14 & $156.3 \pm 81.5$ & $t=0.30 ; \mathrm{df}=34 ; p=0.76$ \\
\hline Body condition & 22 & $-0.013 \pm 0.083$ & 14 & $0.021 \pm 0.107$ & $t=1.08 ; \mathrm{df}=34 ; p=0.29$ \\
\hline \multicolumn{6}{|l|}{ P. patagoniensis } \\
\hline Body size (mm) & 32 & $934.8 \pm 201.3$ & 20 & $852.0 \pm 200.8$ & $t=1.44 ; \mathrm{df}=50 ; p=0.15$ \\
\hline Body mass (g) & 32 & $252.6 \pm 129.2$ & 20 & $168.9 \pm 93.6$ & $t=2.51 ; d f=50 ; p=0.01$ \\
\hline Body condition & 32 & $0.036 \pm 0.178$ & 20 & $-0.058 \pm 0.089$ & $t=2.55 ; d f=50 ; p=0.01$ \\
\hline
\end{tabular}


differences in venom apparatus between taxa (33, 34). While venom in viperid is easily obtained by gentle compression of the venom gland, venom volume from Duvernoy's gland is extremely low; this can be improved through moving the head of the snake (29). However, this procedure may be more detrimental and stressful to snakes and could have contributed to the low survival rates in our snakes. Secondly, this may have also resulted from differences in physiology, habits and consequently in captive requirements between taxa. Captivity conditions that provide higher survival rates for viperids and elapids may not be the most suitable for Philodryas and, therefore, adaptation to captive conditions may be more difficult for the latter.

Seasonality was an important factor affecting captive survival in both species. Survival was significantly lower for individuals captured and admitted in the wet season (spring and summer for $P$. olfersii and spring for $P$. patagoniensis). This contrasts with the results found by Leinz et al. (9) on Bothrops jararacussu, in which captive survival is seemingly lower when animals are captured during autumn and higher when captured during spring and summer (wet season). Those authors suggested that higher survival rates in the wet season could be related to higher resource availability and consequently higher energy stores when faced with the captive environment (9). We suggest that the lower Philodryas survival rates observed in the wet season are more likely due to the high costs and stress involved in reproductive events.

In $P$. olfersii and $P$. patagoniensis gravidity and egg-laying mostly take place during the wet season (September to February) for both species (24). In snakes, this period is characterized by higher physiological stress and costs (35, 36). During the reproduction season females cease feeding, lose body mass, and experience increased mortality rates $(35,36)$. Thus, female $P$. olfersii and P. patagoniensis may be faced with high physiological frailty during this season. In captivity, stressor agents are common, and simple maintenance routines such as cage cleaning, are potential stressors (37). Additionally, handling, restraint, and fluid collection, the procedures involved in venom extraction, are generally associated with higher plasma corticosterone concentrations and thus regarded as stressful incidents in captive animals (38-40). Therefore, what is already a difficult time in the natural life cycle of these animals may be aggravated by laboratory routines.

We hypothesized that animals with larger fat reserves could survive longer in captivity. This hypothesis was tested by verifying the relationship between admission body mass and body condition with survival. However, our analyses did not corroborate this hypothesis. Thus, body mass and body condition were shown to be a poor predictor of captive survival, at least for $P$. olfersii and $P$. patagoniensis. This remains true even after removal of gravid snakes from the analyses. In addition, heavier $P$. patagoniensis individuals lived significantly less than lighter ones. This does not invalidate findings by Cowan (15) of the depletion of all individual fat reserves, nor does it mean that body mass is unimportant, but suggests that larger fat reserves are not crucial to longevity in captivity. We suggest that the consumption of all fat stores observed by Cowan (15) may vary individually and independently of smaller or larger initial fat reserves.

Our results present important implications for the captive management and welfare of snakes maintained for venom production. Being aware of higher vulnerability periods allows us to design effective protocols for further husbandry and management practices with the aim of increasing captive individual survival and welfare. Faced with this, some preventive measures could be adopted looking towards reducing the deleterious impacts of captivity. For example, minimization of excessive handling and cage cleanings and increase of the interval between venom extractions are suggested (13, 41).

Taken together, the analysis of the mortality periods and mortality curves indicated that the first three months of captivity are by far the most critical in terms of individual survival and adaptation to captive conditions. This time should therefore be regarded as an adjustment period to the captive environment and animals should be disturbed as little as possible. In addition, venom extraction should only start after this period. Special care should be given to individuals collected and admitted during the wet season. Our work also showed that some individuals had high longevity. Further important research should focus on the longest surviving 
individuals, especially asking: what features do the longest surviving individuals possess over those surviving less?

\section{CONCLUSIONS}

Firstly, for Philodryas olfersii and Philodryas patagoniensis the first three months in captivity are by far the most critical in terms of individual survival and adjustment to captive conditions. Secondly, capture season strongly affected captive survival. The most critical season for survival in both species was the wet season (spring to summer). And finally, body mass and body condition were poor predictors of captive survival, at least for $P$. olfersii and P. patagoniensis.

\section{ACKNOWLEDGEMENTS}

We are very grateful to Silvia R. TravagliaCardoso, Laura V. P. Narvaes, and Ana C. Parpinelli for assistance with captive maintenance. We are also grateful to the three anonymous referees for their constructive comments on the manuscript. Thanks are also due to Foundation for Administrative Development (FUNDAP) for the financial support to H. B. Braz.

\section{COPYRIGHT}

(C) CEVAP 2012

\section{SUBMISSION STATUS}

Received: September 2, 2011.

Accepted: March 9, 2012.

Abstract published online: March 13, 2012.

Full paper published online: May 31, 2012.

\section{CONFLICTS OF INTEREST}

The authors declare no conflicts of interest.

\section{FINANCIAL SOURCE}

Foundation for Administrative Development (FUNDAP), São Paulo State, Brazil, provided the financial grants.

\section{ETHICS COMMITTEE APPROVAL}

This study was approved by the Butantan Institute Ethics Committee for Animal Use (CEUAIB 482/08).

\section{CORRESPONDENCE TO}

Henrique B. Braz, Laboratório de Ecologia e Evolução, Instituto Butantan, Avenida Dr. Vital Brazil, 1500, CEP 05503-900, Butantã, São Paulo,
SP, Brazil. Phone: +55 1137267222 ext.: 2014. Fax:+55 113726 1505. Email: hbbraz@gmail. com.

\section{REFERENCES}

1. Salomão MG, Albolea ABP, Almeida-Santos SM. Colubrid snakebite: a public health problem in Brazil. Herpetol Rev. 2003;34(3):307-12.

2. Puorto G, França FOS. Serpentes não peçonhentas e aspectos clínicos dos acidentes. In: Cardoso JLC, França FOS, Wen FH, Málaque CMS, Haddad-Jr V, editors. Animais peçonhentos no Brasil: biologia, clínica e terapêutica dos acidentes. São Paulo: Sarvier; 2003. 108-14 p.

3. Salomão EL, Di-Bernardo M. Philodryas olfersii: uma cobra comum que mata, caso registrado na área da $8^{\mathrm{a}}$. Delegacia Regional de Saúde. Arq Soc Zool do Brasil. 1995;14-16:21.

4. Peichoto ME, Leiva LC, Guaimás Moya LE, Rey L, Acosta O. Duvernoy's gland secretion of Philodryas patagoniensis from the northeast of Argentina: its effects on blood coagulation. Toxicon. 2005;45(4):52734.

5. Rocha MM, Paixão-Cavalcante D, Tambourgi DV, Furtado M de F. Duvernoy's gland secretion of Philodryas olfersii and Philodryas patagoniensis (Colubridae): neutralization of local and systemic effects by commercial bothropic antivenom (Bothrops genus). Toxicon. 2006;47(1):95-103.

6. Rocha MM, Furtado M de F. Análise das atividades biológicas dos venenos de Philodryas olfersii (Lichtenstein) e P. patagoniensis (Girard) (Serpentes, Colubridae). Rev Bras Zool. 2007;24(2):410-8.

7. Zelanis A, Rocha MM, Furtado M de F. Preliminary biochemical characterization of the venoms of five Colubridae species from Brazil. Toxicon. 2010;55(12):666-9.

8. Leloup P. Various aspects of venomous snake breeding on a large scale. Acta Zool Pathol Antverp. 1984;78(1):177-98.

9. Leinz FF, Janeiro-Cinquini TRF, Ishizuka MM, Lang LV. Sobrevivência de Bothrops jararacussu (Serpentes, Viperidae, Crotalinae) mantidas em cativeiro. Mem Inst Butantan. 1989;51(1):33-8.

10. Melgarejo-Giménez AR. Criação e manejo de serpentes. In: Andrade A, Pinto SC, Oliveira RS, editors. Animais de laboratório: criação e experimentação. Rio de Janeiro: Fiocruz; 2002. 175-99 p.

11. Serapicos EO, Merusse JLB. Variação de peso e sobrevida de Micrurus corallinus sob diferentes condições de alimentação em biotério (Serpentes, Elapidae). Iheringia, Ser Zool. 2002;92(4):105-9.

12. Murphy JB, Campbell JA. Captive maintenance. In: Seigel RA, Collins JT, Novak SS, editors. Snakes: ecology and evolutionary biology. New York: MacMillan Publ Co; 1987. 165-83 p.

13. Pough FH. Recommendations for the care of amphibians 285 and reptiles in academic institutions. ILAR News. 1991;33(4):S1-2. 
14. McKeown S. General husbandry and management. In: Mader RD, editor. Reptile medicine and surgery. Philadelphia: WB Saunders Company; 1996. 9-19 p.

15. Cowan DF. Diseases of captive reptiles. J Am Vet Med Assoc. 1968; 153(7):848-59.

16. Cowan DF. Adaptation, maladaptation and disease. In: Murphy JB, Collins JT, editors. Reproductive biology and diseases in captive reptiles, SSAR contributions to Herpetology number 1. Lawrence,KS: Society for the Study of Amphibians and Reptiles; 1980. 191-6 p.

17. Ashley BD, Burchfield PM. Maintenance of a snake colony for the purpose of venom extraction. Toxicon. 1968;5(4):267-75.

18. Murphy JB, Armstrong BL. Maintenance of rattlesnakes in captivity. Lawrence, KS: University of Kansas. Museum of Natural History, no 3; 1978. 40 p.

19. Klingenberg RJ. Understanding reptile parasites: a basic manual for herpetoculturists and veterinarians. Lakeside: Advanced Vivarium Systems; 1993.

20. Fowler IR, Salomão MG. Activity patterns in the colubrid snake genus Philodryas and their relationship to reproduction and snakebite. Bull Chicago Herpetol Soc. 1994; 29(10):229-32.

21. Marques OAV, Eterovic A, Sazima I. Snakes of the Brazilian Atlantic Forest. An illustrated field guide for the Serra do Mar range. Ribeirão Preto: Holos; 2004. 205 p.

22. Hartmann PA, Marques OAV. Diet and habitat use of two sympatric species of Philodryas (Colubridae), in south Brazil. Amphibia-Reptilia. 2005;26(1):25-31.

23. Thomas RA. A revision of the South American colubrid snake genus Philodryas Wagler, 1830 [master's thesis]. Texas College Station: Texas A\&M University; 1976. $378 \mathrm{p}$.

24. Fowler IR, Salomão MG, Jordão RS. A description of the female reproductive cycle in four species from the neotropical colubrid snake Philodryas (Colubridae, Xenodontinae). Snake. 1998;28(1-2):71-8.

25. Ribeiro LA, Puorto G, Jorge MT. Acidentes por serpentes do gênero Philodryas: avaliação de 132 casos. Rev Soc Bras Med Trop. 1994;27(Suppl 1):87.

26. de Medeiros CR, Hess PL, Nicoleti AF, Sueiro LR, Duarte MR, de Almeida-Santos SM, et al. Bites by the colubrid snake Philodryas patagoniensis: a clinical and epidemiological study of 297 cases. Toxicon. 2010;56(6):1018-24.

27. Chanhome L, Jintakune $\mathrm{P}$, Wilde H, Cox MJ. Venomous snake husbandry in Thailand. Wilderness Environ Med. 2001;12(1):17-23.

28. Rosenberg HI, Bdolah A, Kochva E. Lethal factors and enzymes in the secretion from Duvernoy's gland of three colubrid snakes. J Exp Zool. 1985;233(1):5-14.

29. Ferlan I, Ferlan A, King T, Russell FE. Preliminary studies on the venom of the colubrid snake Rhabdophis subminatus (red-necked keelback). Toxicon. 1983;21(4):570-4.
30. Jayne BC, Bennett AF. Selection on locomotor performance capacity in a natural population of garter snakes. Evolution. 1990;44(5):1204-29.

31. De Biasi P, Belluomini HE, Hoge AR, Puorto G. Uso de gás carbônico na extração de veneno de serpentes. Mem Inst Butantan. 1976/1977;40/41:167-72.

32. Serapicos EO. Aspectos zootécnicos e patológicos aplicados à manutenção de Micrurus corallinus em biotério (Reptilia - Ophidia - Elapidae) [dissertation]. São Paulo, SP: Faculdade de Medicina Veterinária e Zootecnia da Universidade de São Paulo; 2000. 82 p.

33. Kochva E. The origin of snakes and evolution of the venom apparatus. Toxicon. 1987;25(1):65-106.

34. Kardong KV. Colubrid snakes and Duvernoy's "venom" glands. J Toxicol Toxin Rev. 2002;21(1-2):119.

35. Madsen T, Shine R. Energy versus risk: costs of reproduction in free-ranging pythons in tropical Australia. Austral Ecol. 2000;25(6):670-5.

36. Bonnet X, Lourdais O, Shine R, Naulleau G. Reproduction in a typical capital breeder: costs, currencies, and complications in the aspic viper. Ecology. 2002;83(8):2124-35.

37. Balcombe JP, Barnard ND, Sandusky C. Laboratory routines cause animal stress. Contemp Top Lab Anim Sci. 2004;43(6):42-51.

38. Gregory LF, Gross TS, Bolten AB, Bjorndal KA, Guillette LJ Jr. Plasma corticosterone concentrations associated with acute captivity stress in wild loggerhead sea turtles (Caretta caretta). Gen Comp Endocrinol. 1996; 104(3):312-20.

39. Moore IT, Lemaster MP, Mason RT. Behavioural and hormonal responses to capture stress in the male red-sided garter snake, Thamnophis sirtalis parietalis. Anim Behav. 2000;59(3):529-34.

40. Mathies T, Felix TA, Lance VA. Effects of trapping and subsequent short-term confinement stress on plasma corticosterone in the brown treesnake (Boiga irregularis) on Guam. Gen Comp Endocrinol. 2001;124(1):106-14.

41. Chiszar D, Tomlinson WT, Smith HM, Murphy JB, Radcliffe CW. Behavioural consequences of husbandry manipulations: indicators of arousal and environmental awareness. In: Warwick C, Frye FL, Murphy JB, editors. Health and welfare of captive reptiles. London: Chapman \& Hall; 1995. 186-204 p. 